\title{
The relationship between university youth, $s$ use of electronic groups and their social values
}

\section{Hayam farouk Ibrahim shapan (P.H.D)}

Assistant Professor at group work Department

Faculty of Social Work -Helwan University

\section{Hind Hassan Hammad Hassan (P.H.D)}

Assistant Professor at group work Department

Faculty of Social Work -Helwan University 


\section{Abstract:}

This study aimed to determine the relationship between University youths of electronic groups and their social values. The study measured University youth ability to use electronic groups, The effect of using electronic groups on the value of social responsibility among University youth, and The effect of using electronic groups on the value of social participation among university youth, and The effect of using electronic groups on the value of planning and organizing time among university youth. The study was applied Regular class sample, and applying the law of optimal sample size) (the sample size of students at the Faculty of Pharmacy and the Faculty of Social work at Helwan University (262) single, by (1:23) and the method of proportional distribution was used. the study results indicate that the University youth ability to use electronic groups is high wile in social work.

Keywords: Relationship, university youth, electronic sgroups, social values.

\section{Introduction:}

Youth is considered the capital of the nation promised, present and its future, which is the revolution of the nation, and if the nation realizes how to maintain its most precious revolutions, and how to develop and nurture it, and how to direct it and benefit from it and benefit it was able to perform its mission in life, to achieve the progress of its existence, to reconstruct the earth, and to enrich life and happiness for humanity, and if it did not realize that it wrote to it misery and happiness in its religion and world. .(Halwa,mohmed,2011,p13)

The importance of young people is due to several reasons, the most important of which areTheYouthis the main source of the nation's renaissance and its protective shield, which it relies on to defend its entity and achieve its goals. Young people are the most important sources of change in society because they are the most positive sources of society for all new technology and its use, and they are the most involved in achieving the goals of society. so they understand the future of the country and they are the creative energy that drives the society of the present and tomorrow to progress, so young people should be placed at the top of the priorities. Most contemporary trends in the social and human sciences have concerned the importance of studying the situation of university youth, their attitudes and their role in society, According to the annual statistical 
book on January 1, 2018, the total population of the Arab Republic of Egypt reached 97,006,920 million, and the total number of young people aged 18 to 29 years reached $(21.7$ million) by 23.6 million people, or 23.6 million of the total population.( The Central Agency for Mobilization and Statistics annual statistical book is available on the link,https://www.populationpyramid.net/ar2)Ozlem Dungun a Selma Gules, 2012 Young University like all segments of society faces many overlapping problems both subjective and environmental, the study aimed to know the opinions of students enrolled in colleges to identify the most affected problems and affect their lives within the university, which consisted of problems of housing, nutrition, unemployment, anxiety about the future and problems related to education, where the study relied on the descriptive curriculum, and collected data through a questionnaire form, which applied to (320) students randomly selected, and reached the study Programs and activities must be prepared through universities to help students face their problems so that they have the ability to make decisions about their future, and to get rid of the concerns that accompany them about their studies and their future. .(Doygun\&, Gulec,2012)

Recent developments in the field of communication and information technology have resulted in fundamental changes in communication patterns, methods, mechanisms and phenomena, forcing a necessary review of traditional concepts that have been established in the field of information and communication, such as concepts of the right to communicate, scrutiny of news information, freedom of expression and freedom of knowledge dissemination and circulation in light of the new reality.( Bakhit, 2004,p.41). This was confirmed by a study (Salim Shaaban, 2011)

which found that traditional types of IT and telecommunications are still the most widespread and used in researched social organizations.(Shaaban,2011,p24).Also confirmed by the study AbdelTawab (2006) where its results reached the necessity of choosing what is suitable for our society of communication technology and leaving what does not fit with the values, beliefs and ethics of Egyptian society where this technology is trying significantly to destabilize those values.(Abdul Twab,2006,p1940). The Internet has become a reality in our contemporary life, whether we accept it or oppose it, and the stigma of ignorance and backwardness is attached to anyone who opposes this modern means of communication and the Internet has become the services, sites and programs is the close friend of everyone in the 
family,ithas a big role in influencing all its users whether this effect is negative or Ijaiba. (Halwa, mohmed, 2011, p5). The way in which groups work as a means of social work in achieving their purposes depends on guiding collective life so that the groups with which they work become an effective tool in influencing individuals and guiding their behavior and giving them good directions and values through collective life and this necessarily leads to the satisfaction of their social and psychological needs. (Fahmy, 2000, p.39)

The way in which the group work is served is critical to youth, given the presence of young people in activity groups and working groups, so the social worker has an important and vital role in helping young people to benefit from all the different programs and activities they engage in. (Mahmoud, 2017, p.165)

The group worker seeks to help young people face their problems through group experiences and work on deliberate changes that result in the acquisition of positive skills and values through group interaction.(Jamal,2020,p.204).

The way in which they work with groups is to bring about deliberate social changes with individuals through their collective experiences and social interaction that gives them the opportunity to improve their social performance, and to create the right environment to acquire the characteristics of good citizenship in order to contribute effectively to the development of their society so that these groups become free to instill social values represented by the value of social responsibility, community participation, planning and time planning among university youth.(Bayoumi,2006,p.5)

This was confirmed by the study Awad, (2017) the study belongs to analytical descriptive studies and relied on the use of the social survey method, and applied the study to a sample of (100) students, The study concluded that the university administration plays a role in promoting the principle of moderation and intellectual security for students through the implementation of a range of activities and programs aimed at enhancing moderation and intellectual security among students, and recommended the implementation of activities such as organizing periodic student visits for the doctors and scientists to communicate with them, holding educational exhibitions that emphasize the importance of intellectual security, and hosting some security leaders to discuss students about security and their role in promoting it.( Jaber, Issue 57, Part 7.) 
Where social work in general and the way of serving the community in particular work to help the youth groups university in the face of situations where they are unable to adapt to them through the formation of recreational groups that help the university youth to fill the free time, which is considered fertile ground for accepting destructive ideas and the extent to which this affects the value of taking responsibility and community participation of university youth. (Shams, 2002, p.203).

Study problem:

3) What is The relationship between University youth $s$ of electronic groups and their social values

4) Identify the relationship between the use of electronic groups and the value of social responsibility among university youth

5) Identify the relationship between the use of electronic groups and the value of social participation among university youth

6) Identify the relationship between the use of electronic groups and the value of planning and organizing time among university youth.

\section{Study Objectives:}

The main objective of the study is determined in:

"Defining the relationship between the use of electronic groups and the social values of university youth":

The following sub-objectives emerge from this main objective:

1. Identify the relationship between the use of electronic groups and the value of social responsibility among university youth.

2. Identify the relationship between the use of electronic groups and the value of social participation among university youth.

3. Identify the relationship between the use of electronic groups and the value of planning and organizing time among university youth.

Study hypotheses:

First Hypothesis: There is a statistically significant a positive relationship between the use of electronic groups and social values among university youth

Second Hypothesis: There are no statistically significant substantial differences between the average scoring of users and non-users of egroups of social science a positive relation to their determination of the level of social values among university youth

Third Hypothesis: There are no statistically significant material differences the relationship between the use of electronic groups and the value of social responsibility among university youth. 
Fourth Hypothesis: The fourth hypothesis of the study: "There are no statistically significant substantial differences the relationship between the use of electronic groups and the value of social participation among university youth

Five Hypothesis: There are no statistically significant substantial differences the relationship between the use of electronic groups and the value of planning and organizing time among university youth.

\section{Study Concepts:}

\section{The concept of electronic groups:}

The group is defined as a group of people with the same mutual interests who are able to work together harmoniously and harmoniously by following the basic methods and patterns of groups including primary and secondary groups. (Barker, 1997, p.156)

That is, a number of people, including public loyalty, are joined by a common goal that they influence each other.(Mohammed,1996,p.63 )

It is also known as a small sociology that can guide its effects to develop the organ's abilities and through which the member can see himself, and resolve his conflicts to reach new patterns of behavior. (Awad, 1993, p.33)

Hence, electronic groups can be defined as a type of modern virtual group, such as: They are areas of online work with the aim of collaborating to perform some common tasks, and the areas of the community are private so that only the designated team members who have access to that field know them. ( http ;// Edtech.vt.edu/edtech / $\mathrm{id} /$ ocs / groups. p3).

Howard Ringold's concept of electronic groups as social groups formedin different places around the world, converging, communicating with each other, making new friends, meeting these individuals with common interest, and bringing them together the interactions that are happening in the real world, but not closely, and these interactions are carried out through a communication mechanism, the Internet, which in turn has contributed to electronic formation groups. (Haward, 1993, p.161)

Begato Ronaldo defines electronic groups as an interactive electronic communication involving diverse individuals who share the same ideas and activities. (Beghtto, 2005, p23) 
Jonathan Laser defines them as online clusters whose members do not live in a single geographical spot but are distributed in different parts of the world, bringing together different and different interests, ranging from business to medical groups, and expanding to include various other species. (Jonathon, 2004, p.213)

\section{2- The concept of university youth:}

The intermediate dictionary also defines young people as those who are aware of puberty to the age of masculinity and youth and mean modernity and the youth of the first thing. (Median dictionary, 1974, p.15) Young people are also known as an accompanying psychological condition that passes through a human being characterized by vitality and is related to the ability to learn, flexibility in human relations and responsibility, it is the stage at which a person moves from a stage where he depends on others to a stage where he or she depends on himself. (Hassan, 2006, p.35)

Young sociologists knew that this is the stage at which the individual begins to occupy a place in the constructive social and exercise certain social roles, enabling him to contribute to the building of society. (Hamad, 2012, p.421)

Young people are defined as; The period that begins when society tries to qualify a person to occupy a social position that plays a role or role in its construction and ends when the individual can occupy his place and perform it in the social context according to the criteria of social interaction, thus the analysis of the socials of young people as a group depends on the class and the fullness of the roles played by the young personality in society. (Abu Al Mati, 1999, p.33)

That every student in the university education stage is in the age group of (20-30) years. (Al, Baalbeki, 1991, p.874)

\section{Theoretical Guidelines of the Research: Communication theory:}

Webster's Dictionary defines communication as the core and basis of all simple and complex social interactions, and also defines it as information exchanges between individuals through the customary symbolic system. (Webster, 1986, p.226)

Communication is also defined as a social process involving the source of any individual transmitting a message of any kind and the verbal or non-verbal message transmitted to the recipient through the communication channel and skill plays an important role in selecting and identifying elements of the communication process. (Noeland, 1982, p.35) 
social worker directs interaction to the growth of the group and its members and in order to achieve the goals of the service of the communication group works to increase the productivity of the group, the group with which there is a successful communication in which interactions between members increase; Communication is an important tool for the work of social worker., It can be said that if the goal of serving the community is the growth of the individual, the community and society, its main means is to have a group that takes communication as a means of achieving its goal, whether it is verbal or non-verbal, where the process of communication is influenced by the basic elements of it. They are the sender, the Receiver, the message, as well as the sub-elements (the tool and the reverse nutrition) (.Fahmy, 2001, p.255)

Electronicsis an important means of communication modern and new, the community service must be interested in this means and the study of groups that form through this means and relate to each other to achieve a goal whether verbal or non-verbal and located under the so-called electronic groups formed through websites such as (Masinger, Twitter, Facebook, chat)

as these groups seek to achieve many goals, especially by serving the community, whether they are objectives (recreational, educational or preventive).Based on the theoretical foundations of communication theory that have already been presented, the data of this theory can be used in the current study and considered as one of the main directions of this study through the elements of communication as follows;

Sender: It is intended by the person, group of people, body or device that wants to influence others in a certain way to share certain ideas, trends or experiences, and in this study, the sender is a social worker who works with university youth.

Message: It is to transform ideas from information, trends and experiences into a set of symbols with common meanings between the sender and the future. In this study, the message is information, ideas, trends and experiences that social worker would like to convey to young people on the Internet. 
Receiver: He is the one who receives the message and converts it into the form or symbol that benefits him and in this study also the future considers young people to benefit from another group and receive internet messages through the internet conversation and benefit from it.Media: It is the tool used by the sender to transmit ideas and information to the future and in this study the means can be considered as computers and websites used by young people.

\section{Methodology;}

The study is a descriptive study and relies on the use of the social survey method in the sample for students at the Faculty of Pharmacy at Helwan University and the Faculty of Social work at Helwan University in 2019/2020.

Sample:A regular class sample, and by applying the law of optimal sample size the sample size of students at the Faculty of Pharmacy and the Faculty of Social work at Helwan University (262) single, by (1:23) and the method of proportional distribution was used

Tool: A questionnaire form for university youth on the use of electronic groups and social values among university youth:

\section{The Design of the tool;}

- The researchers designed an electronic questionnaire form using Google Drive Models for university youth by reference to theoretical heritage, previous studies, and questionnaire forms related to the subject of the study.

- The dimensions of the questionnaire form were identified, which were three dimensions: after the value of social responsibility, after the value of social participation, and after the value of time planning and organization.

- The 30 phrases for each dimension have been identified and formulated; The questionnaire form relied on the triangular gradient, so that the response to each phrase (yes, to some extent, no) was given weight (degree): yes (three degrees), to some extent (two degrees), not (one degree)The researchers relied on logical honesty by looking at the theoretical literature, and then analyzing them in order to reach the different dimensions associated with the problem of study. The researchers relied on logical honesty by looking at the theoretical literature, and then analyzing them in order to reach the different dimensions associated with the problem of study. The researchers conducted the virtual honesty of 
the tool after presenting it to a number of (4) faculty members of the Faculty of Social worke Helwan University, and a minimum agreement rate $(75 \%)$, and the form was drafted in its final form., The researchers also conducted statistical stability of a sample of (10) vocabulary from university youth using alpha-kronbach laboratories, and found that most of the correlations of dimensions enjoyed a high degree of stability, and the results were as described in the following table:

Table (1) Results of the stability of the questionnaire form using alpha kronbach laboratories $(\mathrm{N}=10)$

\begin{tabular}{||l||c||c||}
\hline $\mathbf{m}$ & dimensions & $\begin{array}{c}\text { Alpha Kronbach } \\
\text { Coefficient }\end{array}$ \\
\hline \hline $\mathbf{1}$ & After the value of social responsibility & $\mathbf{0 . 8 7}$ \\
\hline $\mathbf{2}$ & After the value of social participation & $\mathbf{0 . 8 2}$ \\
\hline \hline $\mathbf{3}$ & $\begin{array}{l}\text { After the value of planning and } \\
\text { organizing time }\end{array}$ & $\mathbf{0 . 8 9}$ \\
\hline \hline $\begin{array}{l}\text { The stability of the university youth } \\
\text { questionnaire form as a whole }\end{array}$ & $\mathbf{0 . 8 8}$ \\
\hline
\end{tabular}

Table (2) Description of university youth according to the nature of electronic groups

\begin{tabular}{|c|c|c|c|c|c|}
\hline \multirow[t]{2}{*}{$\mathbf{m}$} & \multirow[t]{2}{*}{ Statement } & \multicolumn{2}{|c|}{ social work $(224)=\dot{ }$} & \multicolumn{2}{|c|}{$\begin{array}{c}\text { Pharmacy } \\
(38)=\dot{0}\end{array}$} \\
\hline & & ك & $\overline{\%}$ & (5 & $\%$ \\
\hline 1 & Educational groups & 38 & 17 & 12 & 31.6 \\
\hline 2 & Cultural groups & 27 & 12.1 & 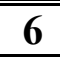 & 15.8 \\
\hline 3 & Social groups & 120 & 53.6 & 10 & 26.3 \\
\hline 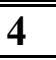 & Medical groups & 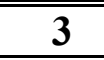 & 1.3 & 9 & 23.7 \\
\hline 5 & Trade groups & 12 & 5.4 & 3 & 7.9 \\
\hline 6 & Chat groups & 88 & 39.3 & 14 & 36.8 \\
\hline
\end{tabular}


- The previous table shows that:The largest proportion of university youth in the specialty of social work using social electronic groups $(53.6 \%)$, followed by chat groups $(39.3 \%)$, and finally medical electronic groups.(\%1.3) The largest proportion of university youth in the pharmacy specialty using chat groups (36.8\%), followed by educational electronic groups (31.6\%), and finally commercial electronic groups $(7.9 \%)$ This indicates that the sample of the study differs in the types of groups used, which focus on social groups, followed by chat groups, but they differed in the use of commercial and medical groups.

The second axis: the level of social values among university youth

Table (3) Level of Social Values among University Youth

\begin{tabular}{|c|c|c|c|c|c|c|c|}
\hline \multirow[b]{2}{*}{$\mathbf{m}$} & \multirow{2}{*}{$\begin{array}{c}\text { Study } \\
\text { Community } \\
\text { dimensions }\end{array}$} & \multicolumn{3}{|c|}{ social work $(224)=\dot{0}$} & \multicolumn{3}{|c|}{ Pharmacy $\quad(38)=\dot{0}$} \\
\hline & & $\begin{array}{c}\text { Arithmetic } \\
\text { average }\end{array}$ & $\begin{array}{l}\text { Standard } \\
\text { deviation }\end{array}$ & Order & $\begin{array}{c}\text { Arithmetic } \\
\text { average }\end{array}$ & $\begin{array}{l}\text { Standard } \\
\text { deviation }\end{array}$ & Order \\
\hline 1 & \begin{tabular}{|l} 
Value of social \\
responsibility
\end{tabular} & 2.4 & 0.27 & 1 & 2.31 & 0.24 & 1 \\
\hline 2 & $\begin{array}{c}\text { Value of social } \\
\text { participation }\end{array}$ & 2.31 & 0.31 & 2 & 2.23 & 0.45 & 2 \\
\hline 3 & \begin{tabular}{|c|}
$\begin{array}{c}\text { Value of time } \\
\text { planning and } \\
\text { organization }\end{array}$ \\
\end{tabular} & 2.21 & 0.23 & 3 & 2.17 & 0.26 & 3 \\
\hline & $\begin{array}{l}\text { ocial values as } \\
\text { a whole }\end{array}$ & 2.31 & 0.19 & $\begin{array}{c}\text { Average } \\
\text { level }\end{array}$ & 2.24 & 0.21 & $\begin{array}{c}\text { Average } \\
\text { level }\end{array}$ \\
\hline
\end{tabular}

- The previous table shows that:The level of social values among university youth as a whole as determined by university youth employing electronic groups in the specialty of social work averaged where the average arithmetic (2.31), indicators according to the calculation average ranking, The level of social values among university youth as a whole as determined by university youth employing electronic groups in the pharmacy specialty averaged at an average of 2.24, and indicators according to the average calculation ranking so there is an agreement between the research community that the level of social values among university youth in the faculty of pharmacy and social work for users of electronic groups is average as the order of values came identical, the value of social responsibility appeared in their first order and then the value of social participation and finally the planning and organization of time, which confirms that the level of social values is the same among university youth from the colleges of pharmacy and social work. 
The third axis: testing the assignments of the study

(1)Test of the first hypothesis of the study: "There is a statistically significant ejective relationship between the use of electronic groups and social values in university youth".

Table (4) Analysis of the simple regression of the relationship between the use of electronic groups and social values among university youth

\begin{tabular}{|c|c|c|c|c|c|c|c|}
\hline $\begin{array}{l}\text { Independent } \\
\text { variable }\end{array}$ & $\begin{array}{l}\text { Research } \\
\text { Community }\end{array}$ & $\begin{array}{l}\text { Number } \\
\text { (n) }\end{array}$ & $\begin{array}{l}\text { steep } \\
\text { factor } \\
\text { B } \\
\end{array}$ & T-Test & F-Test & $\mathbf{R}$ & $\mathbf{R}^{2}$ \\
\hline \multirow{2}{*}{$\begin{array}{l}\text { Use } \\
\text { electronic } \\
\text { groups }\end{array}$} & Social work & 224 & $\begin{array}{l} \\
0.024\end{array}$ & $\begin{array}{l}* * 3.447 \\
\end{array}$ & 11.885 & *0.225 & 0.051 \\
\hline & pharmacy & 38 & "0.31- & $\begin{array}{l}1.738- \\
\end{array}$ & $\begin{array}{l}3.020 \\
\end{array}$ & "0.278 & 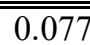 \\
\hline
\end{tabular}

** Significance at $(0.01)$

* Significance at $(0.05)$

- The previous table shows that:Analysis of the simple decline in the relationship between the use of electronic groups and social values among university youth as determined by university youth in the specialization of social service:

- The value of the correlation factor between the independent variable "use of electronic groups" and the variable "social values of university youth" $(0.225)$, which is statistically significant at a moral level (0.01), and indicates a expelled association between the two variables. The result of the $\mathrm{F}=11.885$ test, $\mathrm{Sig}=0.000$ ) refers to the morale of the regression model, with the value of the selection coefficient (0.051), i.e. the use of electronic groups is explained (5.1\%) of changes in social values among university youth.The value of the regression coefficient (-0.024) indicates a expellive relationship between the independent variable and the dependent variable, and the result of the Test $\mathrm{T}(\mathrm{T}=3.447, \mathrm{Sig}=0.000)$ indicates that the effect of the independent variable on the dependent variable is morally and statistically significant at a moral level.(0.01)

- Analysis of the simple decline in the relationship between the use of electronic groups and social values among university youth as determined by university youth in the field of pharm: The value of the correlation factor between the independent variable "use of electronic groups" and the variable "social values of university youth" (0.278), which is not statistically significant. 
- The result of the $P$ test $(F=3.020, \mathrm{Sig}=0.000)$ indicates the inequity of the regression model and the value of the selection factor .(0.077) The value of the regression coefficient $(-0.031)$ indicates that there is no expellive relationship between the independent variable and the dependent variable, and the result of the test $(\mathrm{T}=1.738$, $\mathrm{Sig}=0.000$ ) indicates that the effect of the independent variable on the dependent variable is considered a non-moral effect, which is recognized in the impact of the use of electronic groups by university youth on their social values.

This makes us accept the first imposition of study in part for university youth in the specialty of social work, which is that "there is a statistically significant e-expulsion relationship between the use of electronic groups and social values among university youth and its attachment to the percentage of university youth in the specialization of pharmacy is not influential and may be due to the nature of the study, which differs from the students of social service."

The second imposition test of the study: "There are no statistically significant fundamental differences between the average scores of users of electronic groups in the specialization of social work and pharmacy in relation to their determination of the level of value of social responsibility among university youth

Table (5) Moral differences between average grades of users of electronic groups in the specialization of socialwork and pharmacy in relation to their determination of the level of value of social responsibility among university youth $(n=262)$

\begin{tabular}{|c|c|c|c|c|c|c|c|}
\hline dimensions & $\begin{array}{l}\text { Research } \\
\text { Community }\end{array}$ & $\underset{(n)}{\text { Number }}$ & $\begin{array}{c}\text { Arithmetic } \\
\text { average }\end{array}$ & $\begin{array}{l}\text { Standard } \\
\text { deviation }\end{array}$ & $\begin{array}{l}\text { Degrees } \\
\text { of } \\
\text { Freedom } \\
\text { (df) }\end{array}$ & $\begin{array}{c}\text { Value } \\
T\end{array}$ & Indication \\
\hline \multirow{2}{*}{$\begin{array}{c}\text { Value of } \\
\text { social } \\
\text { responsibility }\end{array}$} & Social work & $\overline{224}$ & 2.4 & 0.27 & \multirow{2}{*}{260} & \multirow{2}{*}{1.941} & \multirow{2}{*}{ Non-D } \\
\hline & pharmacy & 38 & 2.31 & 0.24 & & & \\
\hline
\end{tabular}

** Significance at $(0.01)$

* Significance at (0.05)

The previous table shows that:There are no statistically significant fundamental differences between the average grades of egroup users in the specialization of social work and pharmacy in relation to their determination of the level of value of social responsibility among university youth as a whole. This makes us accept the second imposition of the study, which is that "there are no statistically significant fundamental differences between the average grades of users of electronic groups in the specialization of social work and pharmacy in relation to their determination of the level of 
value of social responsibility among university youth, which confirms the impact of the use of university youth The more young people use electronic groups, the less social responsibility they have".

Test of the third imposition of the study: "There are no statistically significant fundamental differences between the average scores of users of electronic groups in the specialization of social work and pharmacy in relation to determining the level of value of social participation among university youth".

Table (6) Moral differences between average grades of users of electronic groups in the specialization of social work and pharmacy in relation to determining the level of value of social participation among university youth $(n=262)$

\begin{tabular}{|c|c|c|c|c|c|c|c|}
\hline dimensions & $\begin{array}{c}\text { Research } \\
\text { Community }\end{array}$ & $\begin{array}{c}\text { Number } \\
\text { (n) }\end{array}$ & $\begin{array}{c}\text { Arithmetic } \\
\text { average }\end{array}$ & $\begin{array}{l}\text { Standard } \\
\text { deviation }\end{array}$ & $\begin{array}{l}\text { Degrees } \\
\text { of } \\
\text { Freedom } \\
\text { (df) } \\
\end{array}$ & $\begin{array}{c}\text { Value } \\
\mathbf{T}\end{array}$ & Indication \\
\hline \multirow{2}{*}{$\begin{array}{c}\text { Value of } \\
\text { social } \\
\text { participation }\end{array}$} & Social work & 224 & 2.31 & 0.31 & \multirow{2}{*}{260} & \multirow{2}{*}{1.367} & \multirow{2}{*}{ Non-D } \\
\hline & pharmacy & 38 & 2.23 & 0.45 & & & \\
\hline
\end{tabular}

** Significance at (0.01)

* Significance at (0.05)

The previous table shows that there are no statistically significant fundamental differences between the average grades of egroup users in the specialization of social work and pharmacy in relation to their determination of the level of value of social participation among university youth as a whole .This makes us accept the third hypothesis of the study, which is that "there are no statistically significant fundamental differences between the average grades of users of electronic groups in the specialization of social work and pharmacy in relation to their determination of the level of value of social participation among university youth, and this confirms the impact of the use of electronic groups on the value of social participation among university youth".

Test of the fourth imposition of the study: "There are no statistically significant substantial differences between the average scores of users of electronic groups in the specialization of social work and pharmacy in relation to their determination of the level of value of planning and organization of time in university youth". 
Table (7) Moral differences between average grades of users of electronic groups in the specialization of social work and pharmacy in relation to determining the level of value of planning and organizing time among university youth $(n=262)$

\begin{tabular}{|c|c|c|c|c|c|c|c|}
\hline dimensions & $\begin{array}{l}\text { Research } \\
\text { Community }\end{array}$ & $\begin{array}{c}\text { Number } \\
\text { (n) }\end{array}$ & $\begin{array}{l}\text { Arithmetic } \\
\text { average }\end{array}$ & $\begin{array}{l}\text { Standard } \\
\text { deviation }\end{array}$ & $\begin{array}{l}\begin{array}{c}\text { Degrees } \\
\text { of }\end{array} \\
\text { Freedom } \\
\text { (df) }\end{array}$ & $\begin{array}{l}\text { Value } \\
T\end{array}$ & Indication \\
\hline \multirow{2}{*}{$\begin{array}{l}\text { Value of } \\
\text { time } \\
\text { planning } \\
\text { and } \\
\text { organization }\end{array}$} & Social work & $\begin{array}{l}\text { Social } \\
\text { work }\end{array}$ & 2.21 & 0.23 & \multirow{2}{*}{260} & \multirow{2}{*}{1.107} & \multirow{2}{*}{ Non-D } \\
\hline & pharmacy & 38 & 2.17 & 0.26 & & & \\
\hline
\end{tabular}

The previous table shows that: There are no statistically significant fundamental differences between the average scores of egroup users in the specialization of social work and pharmacy in terms of determining the level of value of time planning and organization among university youth as a whole. This makes us accept the fourth imposition of the study, which is that "there are no statistically significant fundamental differences between the average scores of users of electronic groups in the specialization of social work and pharmacy, in terms of determining the level of value of planning and organizing time among university youth, confirms the relationship between the use of electronic groups by university youth and the value of time planning and organization".

Fifth imposition test of the study: "There are no statistically significant fundamental differences between the average scores of users of electronic groups in the specialization of social work and pharmacy in relation to their determination of the level of social values of university youth as a whole".

Table (8) Moral differences between average grades of users of electronic groups in the specialization of social service and pharmacy in relation to their determination of the level of social values among university youth as a whole $(n=262)$

\begin{tabular}{|c|c|c|c|c|c|c|c|}
\hline dimensions & $\begin{array}{l}\text { Research } \\
\text { Community }\end{array}$ & $\begin{array}{c}\text { Number } \\
\text { (n) }\end{array}$ & $\begin{array}{l}\text { Arithmetic } \\
\text { average }\end{array}$ & $\begin{array}{l}\text { Standard } \\
\text { deviation }\end{array}$ & $\begin{array}{l}\begin{array}{l}\text { Degrees } \\
\text { of } \\
\text { Freedom } \\
\text { (df) }\end{array} \\
\end{array}$ & $\begin{array}{c}\text { Value } \\
\mathrm{T}\end{array}$ & Indication \\
\hline \multirow{2}{*}{$\begin{array}{c}\text { Social } \\
\text { values as a } \\
\text { whole }\end{array}$} & Social work & 224 & 2.31 & 0.19 & \multirow{2}{*}{260} & \multirow{2}{*}{2.145} & \multirow{2}{*}{ Non-D } \\
\hline & pharmacy & 38 & 2.24 & 0.21 & & & \\
\hline
\end{tabular}


The previous table shows that:There are no statistically significant fundamental differences between the average scores of e-group users in the specialization of social work and pharmacy in relation to their determination of the level of social values of university youth as a whole. This makes us accept the fifth imposition of the study, which is that "there are no statistically significant fundamental differences between the average grades of users of electronic groups in the specialization of social work and pharmacy in relation to their determination of the level of social values among university youth as a whole .This emphasizes the relationship between the use of electronic groups and social values (social responsibility, community participation - planning and organization of time) among university youth".

Discuss search results The aim of the research is to determine the relationship between the use of electronic groups and social values among university youth through the test of the imposition of the following study " There is a statistically significant expellive relationship between the use of electronic groups and social values among university youth and the results of the study explained by accepting the imposition of the study in part, where there appeared a expulsion link between the use of electronic groups and the social values of university youth in the specialization of social work and was rejected for university youth from the specialization of pharmacy, This result differs with regard to university youth from the specialization of social work with the results of the study (Hassanein, 2006) where his study showed that there is a change in the values of university youth, especially with regard to social responsibility as a result of the use of the Internet, where its results showed that the use of the Internet by university youth leads to a change in the positive values of university youth and the emergence of negligence in duties and responsibilities towards others, and also differs with the results of the study (Ahmed, 2010)Which confirmed that youth culture affects the values of university youth from the specialization of social work where this is reflected in the emergence of negative values they have such as poor interest in others, and a weak sense of responsibility towards societal problems, which contributes to spreading the spirit of negativity and indifference and weak cohesion and cohesion to them socially In contrast, the results of the study are consistent with scientific research (Mahmoud, 2012), which confirmed in the results of his study that social media and internet networks have a positive impact on the 
values of university youth from the specialization of social work, they help to provide sufficient knowledge and information about social responsibility and teach them ways of helping others and explain the concept of responsibility However, the same scientific research confirms the negative impact of social networking sites or social networks shows the weakness of participation among university youth through the preoccupation of young people with social networks and marginalization of participation roles, and that it does not allow time to participate in voluntary charity and also develops among the talkie youth and makes him confused in determining his needs and unable to perform his social roles.It also differs with the results of the study (Sharqawi and Al-Qahtani), which explained that the entry of young people into electronic groups and forums leads to a weak relationship between young people and their families, and that the difference between the personalities involved in the electronic groups affects and affects each other, which reflects on their values..The result of the impact of the use of electronic groups on social values can be explained in a way that is directly to young people who specialize in social work without pharmacy, which may be due to the nature of the study of social work, which supports the values of social responsibility, participation, planning and organization of time, social responsibility is one of the core values underlying the philosophy of community, which is one of the basic social work disciplines Which has been identified by (GiselaKonopka)ss since the inception of the method, which is strengthened through study and through field training for social work students, and participation is also the basis of collective work within different groups, including electronic groups, which are strengthened during training for university youth, in addition to all specialty courses that provide multiple information, knowledge and skills .Related to social values and support among university youth, this may explain the result of Schedule 8, which shows that social groups are the most joined by university youth from the specialization of social work without pharmacy, as the highest percentage of pharmacy students join chat groups more.The results of the study also indicated that there are no statistically significant fundamental differences between the average scores of e-group users in the specialization of social work and pharmacy in relation to their determination of the level of social values among university youth as a whole, which confirms that the level of social values among university youth does not exist statistically significant differences between them 
Statistical procedures used in the study, the data were processed by computer using the program (spss.v. 24.0) Statistical Packages for Social Sciences, and the following statistical methods were applied: The data was collected from 1/7/2020 to 15 August 2020, and the data was then processed through the computer using SPSS.V. 24.0) Statistical packages of social sciences, the following statistical methods have been applied: repetitions and percentages, arithmetic average, standard deviation, range, stability factor (Alpha. Kronbach), simple regression analysis, Pearson correlation coefficient, identification laboratory, test $(\mathrm{T})$ of two independent samples, and one-way contrast analysis.

\section{Recommendations:}

The current study recommends

1. Caring for the youth sector and strengthening its social values

2. Clarifying the importance of using electronic groups among university youth

3. Establishing and preserving social values in light of the use of electronic groups

4. Maintaining the value of social responsibility, participation and organizing time among university youth

5. Caring and highlighting the university youth in theoretical college 


\section{References:}

Abdel Ghani Mohammed Hassan (1996). Principles of Sociology, Cairo, Center for Performance Development and Development

Abdul Tawab Hana Rabie (2006). The trends of female students towards the use of communication technology in identifying women's issues" study applied to the students of the 4th Division of the Faculty of Social Service, Fayoum University, 19th Scientific Conference, Helwan University, Faculty of Social Service.

A genuine Webster (1986). New collegiate Dictionary (massachusetts; publisher, spring filial.

Al-Baalbeki Munir (1991). Dictionary of Supplier, Lebanon, Beirut, Dar al-Alam for Millions

Al-Masih, Najla Ahmed (2010). The negative effects of chat culture on social values among university youth depict a proposal from the perspective of general practice in social service to mitigate it, journal studies in social service and humanities, Helwan University, Faculty of Social Service, Issue (29), Part II

Arabic Language Complex (1974). Intermediate Dictionary, Cairo, House of Knowledge

Awad Jaber Sayed (1993). Working with groups, Alexandria, Al-Amrani Press of Offset.

Bakhit Al Saye (2004). Internet is a new means of communication, Cairo, University Book House.

Bayoumi Ibrahim Marri (2003). Communication and Applications in Social Service, Cairo, Nour Al-Iman Printing.

Beghtto Ronaldo (2005). community Buiding strategies in online fanzienes, N.Y,Journal of popular culture

Fahmy Nassif MenqarYus (2000). Practicing professional processes and working with groups field studies and experiments, Cairo, Scientific Office

Fahmy Nassif Menqarius and others (2011). Communication and its applications in social service, reference mentioned above

Halawa, Mohammed Al Sayed, Raja Ali Abdel Ati, (2011). Social Relations between Young People and Facebook Chat: University Knowledge House Alexandria.

Hamad Intisar Ombia Abdullah (2012). Young people's tendencies towards the values of the culture of globalization, Libya, Dar al-Hikma, I1

Hassan Abdel Moncef Ali (2006). Practice social service in the field of youth care and their judges, Cairo, Dar Nahda Egypt

Hassanein Zaghloul Abbas (2006). A proposed guidance program from the perspective of community service to counter the negative effects of the Internet on university youth, journal studies in social service and humanities, Helwan University, Faculty of Social Service, Issue (20), April 2,

HawardRihing old, (1993). Virtual community,(http;// www.com, user /h(R) vcboal http;// Edtech.vt.edu/edtech / id/ ocs / groups.

Ibrahim Bayoumi Merhi (2006). Founded working with groups and their bright operations, Cairo, Nour al-Iman, . 
Jaber Amal Awad (2017). Towards a proposed conception of the role of the group's specialist to enhance the intellectual security of university youth (study applied to students of the Higher Institute of Social Service in Aswan), research published in the Journal of Social Service - Egyptian Society of Social Workers, Egypt, Issue 57

Jamal Rabab Salem (2020). Social service and youth care, reference mentioned above

Jonathon layzer; et,al(2004).collection user requirements in virtual population Acase study (www.user pager, edu / Nbuchwait / paorslazar, htm

Maher Abu Al-Maati and others (1999). General Practice of Social Service in Youth Welfare, Cairo, Leadership Market

Mahmoud Abdul Muhai Hassan Saleh (2017). Social service and professional practice areas, Alexandria, Modern University Office

Mahmoud, Khaled Saleh Saleh (2012). The impact of social networks on social values among university youth is a proposed conception from the perspective of the general practice of social service, journal of studies in social service and humanities, Helwan University, Faculty of Social Service, Issue (33), Part 1

Mr. Mohamed Halawa, Raja Ali Abdel Ati(2011). Social Relations for Young People from Internet Chat, Facebook, Cairo, University Knowledge House

NoelandRetatims (1982). Dictionary of social welfare clondon, Rutledge and kegampaul

OzlemDoygun a, Selma Gulec(2012). The problems faced by university students and proposals for solution, Uludag University, Turkey, Education Faculty Elementary Education Department Academic Membe..

Robert, Barker (1997). The social work dictionary, su.A, 3rd edition N.A.S.W press

Shaaban Salim Salim Mohammed (2011). The relationship between the use of ICT and "the professional performance of the social plan in social organizations in Port Said" specialized semi-annual scientific journal and court, issue 30, Helwan University, Faculty of Social Service, April

Shams Mohammed al-Din Ahmed (2002). Working with groups in the vicinity of social service, Helwan University, University Publishing and Distribution Center

Sharqawi, Mohammed Kamel Mohammed and Al-Qahtani, AwatifBint Yahya (2015). The influence of the characters of the patterns of virtual groups on their dynamics descriptive study applied to the forums of Princess NouraBint Abdul Rahman University, Journal of Studies in Social Service and Humanities, Helwan University, Faculty of Social Service, Issue (39), Part 3, October

The Central Agency for Mobilization and Statistics annual statistical book is available at the link/ https://www.populationpyramid.net/ar2) https://www.populationpyramid.net/ar2) 
